\title{
Humor y copla. Hacia una educación sentimental*
}

\author{
María ROSAL NADALES**
}

\begin{abstract}
Resumen
La educación sentimental durante la dictadura franquista tuvo en la copla una poderosa aliada, gracias al éxito popular y a su enorme difusión. Abordamos en este trabajo el estudio de la copla desde la perspectiva de su carácter de manual normativo de las costumbres de la época y de las imágenes de mujer que transmite. Los modelos patriarcales se difunden a través de la copla, habitualmente por medio de textos dramáticos. Sin embargo, aunque en menor medida, también se publicaron obras que basan en el humor la construcción de imágenes de mujeres que recurren a los estereotipos para ridiculizar modelos y situaciones. Centramos el análisis en un corpus de obras de Rafael de León.
\end{abstract}

Palabras clave: Estereotipos, Franquismo, Patriarcado, Feminismo, Copla.

\footnotetext{
* Recibido el 29 febrero 2020, aceptado el 30 junio 2021.

** Profesora Titular, Departamento Ciencias del Lenguaje, Universidad de Córdoba, Córdoba, España. fe1ronam@uco.es/ https://orcid.org/0000-0002-6053-910X 
Humor and Verse. Towards a Sentimental Education

\begin{abstract}
Sentimental education during during Franco's dictatorship had had a powerful ally in verse due to its popular success and its widespread diffusion. In this work we address the study of verse from the perspective of its normative nature, which is based on the habits of the time and on the images that women transmit. Patriarcal models spread through verse, usually by plays. Nonetheless, works founding the construction of women images on humor and drawing on stereotypes to ridicule models and situations were published, but to a lesser extent. Our corpus of analysis is Rafael de León's works.
\end{abstract}

Keywords: Stereotypes, Franco's Dictatorship, Patriarchy, Feminism, Verse. 


\section{La época}

Tras la Guerra Civil (1936-1939), España queda devastada. La miseria, el hambre, la privación de libertad, las represalias y el miedo forman parte de la cotidianidad de la mayor parte de la población. La sociedad patriarcal, reforzada por la ideología fascista y el nacionalcatolicismo, privará a las mujeres de derechos fundamentales y encontrará en la copla un cauce de difusión de los modelos femeninos y masculinos. En este contexto, la limitación de la vida de las mujeres y la justificación de diversos tipos de violencia (psicológica, física, sexual, económica, patrimonial), es propagada eficazmente por la Sección Femenina, en nombre del Régimen y de Dios.

La nueva sociedad se construye bajo la dirección de una férrea moral católica que aísla a las mujeres en el espacio privado, sin acceso a una economía independiente. La sumisión femenina era propugnada por todos los discursos y desde todos los ámbitos: las leyes, el confesionario, las revistas (Medina, El ventanal, Teresa) y los consultorios sentimentales. Especial relevancia tuvo el consultorio de Elena Francis ${ }^{1}$, muy popular durante el primer franquismo, dirigido al público femenino durante casi cuarenta años (1947-1984). Abordaba temas de belleza, cocina y muy especialmente consejos de índole sentimental.

España se cierra al exterior al final de la Guerra Civil. Las influencias extranjeras se consideran nefastas, peligrosas o pecado: "La posición de la mujer española está hoy como en la Edad Media, Franco le arrebató todos los derechos civiles", recoge Carmen Martín Gaite (1987:30), en una cita del corresponsal del New York Posten 1945.

El lugar de la mujer casada es el hogar y su función consiste en atender al marido y a los hijos e hijas. Para la soltera, la atención a los mayores, suplió muchas expectativas de vida personal. Las leyes impedirán que las mujeres realicen trabajos remunerados una vez casadas: "Los sucesivos gobiernos franquistas van a desarrollar una legislación para alejar a la mujer del mundo laboral, empezando por el Fuero del Trabajo promulgado el 9 de marzo de 1938" (Ramos Rovi, 2017:165). Esa prohibición se mantendrá hasta la década de los sesenta, con la aprobación de la Ley de Derechos Políticos, Profesionales y del Trabajo de la Mujer. Las necesidades crecientes de mano de obra justifican que las mujeres, apartadas de talleres y fábricas por las legislaciones anteriores, accedan al mundo laboral. Muy significativa es la alocución de Pilar Primo de Rivera, en su discurso en la presentación a las Cortes de dicha Ley en 1961: "No es, ni por asomo, una ley feminista... En modo alguno queremos hacer del hombre y la mujer dos seres iguales; por naturaleza ni por fines a cumplir en la vida podrán nunca igualarse" (Primo de Rivera apud Moraga, 2008:247).

Los trabajos propiamente femeninos son definidos por la Sección Femenina en relación con la enfermería, los cuidados dentro del hogar y con la artesanía: "La S. F. ha desviado la atención de la mujer hacia profesiones netamente femeninas [...] ha creado para la mujer una serie de trabajos remunerados y exquisitos redimiendo a tanta mujer del pueblo del difícil y cansado camino de los libros" (Medina, apud Martín Gaite, 1987:69²). Tal y como señalaba el Servicio Social (Decreto 7 de octubre de 1937): "Su creación se ha debido a la situación de guerra y a la necesidad de incorporar a las mujeres en la ayuda a las tareas del Estado" (Bosh; Ferrer; Gili, 1999:182). Este trabajo, relacionado en principio con el Auxilio Social en hospitales, extendió sus obligaciones a las mujeres solteras entre 17 y 35 años (Bosh; Ferrer; Gili, 1999).

Las relaciones de poder entre hombres y mujeres encuentran su representación en la copla ${ }^{3}$, que se convierte en un espacio idóneo para la transmisión normativa de modelos de conducta. Sus letras se constituyen en un ejemplario de situaciones y conflictos que será difundido extensa e intensamente a través de las ondas radiofónicas y del cine folklórico, fundamentalmente de ambientación andaluza y aragonesa, durante el primer franquismo (1940-1960). "Es una canción andalucista en la imaginería, la melodía y la pronunciación, vinculada a una España agrícola y

\footnotetext{
1 El consultorio estaba patrocinado por una empresa de cosméticos que diseñó el personaje de Elena Francis. Sobre el revuelo que se organizó cuando se supo que no existía da cuenta Imbert (1982).

2 Texto publicado en la revista Medina el 1 de noviembre de 1942, con el título "Diario de una estudiante".

3 Vid.: Moix (1993), Acosta Díaz et al (1997); Hurtado Balbuena (2006); Reina (2009); Román (2010). Rosal Nadales (2011).
} 
provinciana. Tiene por lo tanto frecuentes conexiones con la lírica tradicional” (Vázquez Montalbán, 2000:XII).

Las ondas radiofónicas inundan los hogares españoles, de manera muy intensa, durante los años cuarenta y cincuenta. Los arquetipos femeninos y masculinos impregnan unos textos en los que las transgresiones de las mujeres son castigadas ejemplarmente. Se convierten, así en referencias de conducta para ambos sexos en correlación con las normas y modelos propugnados por el Estado, la Iglesia y la Sección femenina

Los valores del Régimen se difunden en una cultura controlada por la censura. Gran popularidad alcanzó el cine folclórico en el que se representan muchas de las historias de las coplas, llenas de tipismo, tanto en la reproducción de escenarios como en la caracterización de los personajes. Son protagonizadas por intérpretes ${ }^{4}$ muy valoradas por el público, que conocía bien sus canciones: Suspiros de España (1939) con Estrellita Castro; Filigrana (1949) con Concha Piquer; La Lola se va a los puertos (1947) y Lola, la piconera (1951) con Juanita Reina, Embrujo (1947) y La niña de la venta (1951) interpretadas por Lola Flores.

Las coplas se constituyen, por tanto, en documentos sociales e históricos. Son textos literarios de profundas raíces populares y en ellos es posible rastrear los postulados de conducta que sirvieron de referencia a varias generaciones durante la dictadura franquista en España.

Aunque, desde una perspectiva sociocultural, no concebiríamos la España franquista como un bloque único y cohesionado, entendemos que, pese a las diferencias en la recepción, la copla supone un notable instrumento de comunicación y por tanto un vehículo de transmisión de modelos y estereotipos. Tampoco podemos ignorar la influencia de otras corrientes musicales, como señala Carmen Marín Gaite en el artículo "Cuarto a espadas sobre las coplas de la posguerra" (1972), publicado en la revista Triunfo, a propósito del libro de Manuel Vázquez Montalbán, Crónica sentimental de España.

Durante el Bachillerato y en los primeros años de Universidad, las chicas de provincias de mi tiempo hacíamos a diario un alto en el estudio de las monocotiledóneas y el mester de clerecía, para acercarnos a la radio a la hora de la merienda y escuchar, mirando la calle entre visillos, en un silencio veteado por la luz de la puesta del sol, los sones de Bonet de San Pedro, de Machín, de Raúl Abril, de la Piquer. Alimentaban, era el pan de cada tarde" (Martín Gaite 1972:36).

Nuestro análisis se sirve también de la crítica literaria feminista para abordar las imágenes de mujeres que popularizan los discursos narrativos y dramáticos de las coplas. "Por eso son importantísimas las piezas subculturales, porque se convierten en huellas de la sentimentalidad, moralidad, sabiduría convencional y por lo tanto en índices del comportamiento de las masas" (Vázquez Montalbán, 2000:X). En esta ocasión, la mirada se centra en un corpus de ocho coplas cuyas letras que se valen de recursos humorísticos para modular argumentos que resulten ejemplarizantes para la sociedad.

La capacidad del humor para cargar de sentido un mensaje ha sido ampliamente tratada (Hidalgo Downing; Iglesias Recuero, 2009; Gómez Capuz, 2002; Núñez Ramos, 1984). El uso discursivo del humor facilita la crítica social (Bordiera; Martínez; Mompart, 2015). A través de diversos recursos como coloquialismos, hipérboles, dilogía y metáforas las coplas construyen personajes que, con sus actuaciones, revisan los modelos socialmente aceptados.

Son coplas muy conocidas, que gozaron de gran popularidad hacia los años cincuenta del pasado siglo, obras de Rafael de León, "poeta aristócrata que renunció a su linaje, bohemio y forajido de los círculos intelectuales al uso, participaba de la amistad de Federico García Lorca y de buena parte de su estética" (Téllez, 2012:133). En estrecha colaboración con él, en la composición y en la música, se encuentran Antonio Quintero y Manuel Quiroga.

\footnotetext{
4 Concha Piquer, Pastora Imperio, Estrellita Castro, Imperio Argentina, Lola Flores, Juanita Reina, Carmen Sevilla, Marifé de Triana.
} 


\section{De la perfecta novia a la perfecta casada}

Las coplas narran pequeñas historias cotidianas, con las que los oyentes pueden identificarse. Son generalmente obras dramáticas en las que predomina la expresión dolorosa de sentimientos como el amor, los celos o la venganza. Su estructura es sencilla, lo que le permitió llegar a amplios sectores de población, en gran parte analfabeta. De manera general, tras la presentación del personaje, que suele ser femenino, aparece el conflicto y la resolución del problema, acompañado o no de estribillo.

Sería absurdo intentar decir que las canciones de Rafael de León son como las novelas de Flaubert. Pero me parece muy sensato admitir que fueron más útiles al pueblo español de los años cuarenta que las novelas de Flaubert, fundamentalmente porque la organización vital y cultural de las masas en el siglo XX queda más al nivel de Rafael de León o los Beatles (son meros ejemplos) que de Flaubert (Vázquez Montalbán, 2000:XII).

Entre los temas, la sumisión y la aceptación del sufrimiento encuentran su expresión en las letras de las coplas, en consonancia con el perfil de mujer diseñado por el régimen franquista. Se reactualizan modelos tan lejanos en el tiempo como el de La Perfecta casada de Fray Luis de León y el concepto burgués decimonónico del "ángel del hogar". Los escenarios en los que se ubican las mujeres consideradas buenas son los del espacio privado. La mujer casada permanece al cuidado del hogar. Para la mujer soltera, la cancela o la ventana configuran el imaginario de la espera del pretendiente y de la promesa de matrimonio. En ambas, la costura es su atributo, tanto para atender a la familia, como para bordar el ajuar.

Transgredir estas normas suele traer sonadas desgracias, de las que las letras de las coplas dan la crónica y sus intérpretes cantan con gran teatralidad. Así retratan, por ejemplo, el sufrimiento de Triniá y de María de la $O$, por abandonar el verdadero amor cegadas por la avaricia, en pos de un hombre rico.

Aunque el dolor y el dramatismo prevalecen en las coplas, también triunfaron otras que se valen del humor para mostrar de manera indirecta los modelos prescriptivos para las mujeres. En este sentido, nuestra mirada se centra en la representación de estereotipos y en los recursos retóricos con los que se construyen los modelos de conducta femenina a través del humor, en contraposición con otras letras de tono más serio.

Abordamos el análisis de un corpus ${ }^{5}$ de coplas que muestran diversos argumentos en torno al vestido femenino, maquillaje, joyas, compañía, relaciones, acceso al conocimiento y estado civil. En ellas se dibujan las características que definen a la mujer española del primer franquismo: cristiana, decente, sin estudios, casada y sumisa.

$\mathrm{El}$ análisis se estructura en torno a tres núcleos interrelacionados en los que confluyen modelos y estereotipos de género transmitidos a través de la cultura popular y de los que se encuentran ejemplos en el refranero. La mujer sumisa e ignorante, al servicio de los demás será el modelo largamente sostenido durante las primeras décadas de posguerra.

A) Arquetipo de la mujer española

Carmen de España

Mi trigo limpio

B) El saber de las mujeres. La lectura

Lolita la musaraña

\footnotetext{
${ }^{5}$ Las coplas que forman este corpus pueden consultarse en versiones cantadas por diferentes intérpretes: https://www.youtube.com/results?search_query=carmen +de+espa\%C3\%B1a https://www.youtube.com/results?search query $=$ mi + trigo + limpio

https://www.youtube.com/results?search query=lolita+la+musara\%C3\%B1a https://www.youtube.com/watch?v=axFio7K8yG8

https://www.youtube.com/results?search query=los + ni\%C3\%B1os +de+la + gabriela

https://www.youtube.com/results?search query $=a+l a+l i m a+y+a l+l i m o n$

https://www.youtube.com/watch?v=TGIFxEfn7NI

https://www.youtube.com/watch?v=FfC3duGxy5k

[Acceso 8 enero 2020].
} 


\section{La niña de la estación \\ Los niños de la Gabriela \\ C) La solterona \\ A la lima y al limón \\ Soltera \\ Compuesta y sin novio}

\section{A) Arquetipo de la mujer española}

El paradigma de la mujer española aparece claramente delimitado en Carmen de España (1952). Su protagonista expresa en primera persona las claves del momento histórico: una España cerrada al exterior, ensimismada en el espejo del nacionalcatolicismo.

Carmen de España, valiente,

Carmen con bata de cola,

pero cristiana y decente.

Lejos de la mirada romántica del siglo XIX, labrada por Prosper Merimée (Carmen, 1845) y por la ópera de Bizet (1875), la Carmen de la copla supone una revisión de sus predecesoras y un rechazo de sus postulados para convertirse en baluarte de la moral reduccionista instaurada por el Régimen:

Pero no es verdad la historia

que de mí escribió un francés,

al que haría en pepitoria

si volviera aquí otra vez.

La voz de la protagonista es fuerte y poderosa. Levanta sus argumentos sobre la columna de la moral vigente con tono serio y rotundo. Frente a esta, el sujeto lírico de Mi trigo limpio es una voz masculina que se dirige con autoridad a una mujer: María Manuela, su esposa, a la que no llegamos a oír, aunque del discurso del marido se desprende que está obedeciendo sus órdenes.

Esta copla se popularizó con el título de su primer verso (María Manuela, ime escuchas?). Cantada ${ }^{6}$ por Pepe Pinto, detalla el canon de belleza y honestidad para la mujer casada. Su órdenes y comentarios oscilan entre el halago y la amenaza, con la justificación de la violencia del marido.

Ya desde el título, Mi trigo limpio reúne varios mensajes simbólicos, tanto por el posesivo, que recuerda la posición de dependencia de la mujer respecto al esposo, como por la metáfora (trigo limpio). Es una expresión popular bien conocida para referirse a persona sin tachas y de conducta recta. De hecho, es más frecuente su uso en sentido negativo, para calificar a alguien que no es de fiar (no es trigo limpio).

Las posibilidades de las mujeres de ser económica y socialmente independientes, durante el primer franquismo, eran nulas y su reclusión en el hogar constituía el modelo aceptado. Debían ser naturales, sin trampas ni disimulos, sin secretos ni actitudes que pudieran dañar la honra del varón. Así Mi trigo limpio se constituye en un inventario de conductas censurables en una esposa. Los núcleos temáticos abordan el vestido, los adornos y el arreglo en general de la mujer casada. Con tono humorístico, el marido va relatando una serie de comentarios normativos.

Yo de vestíos no entiendo, pero... ¿̇te gusta de veras ese que te estás poniendo? Tan fino, tan transparente, tan escaso y tan ceñío, que a lo mejor por la calle te vas a morir de frío.

\footnotetext{
${ }^{6}$ Fue parodiada por los hermanos Calatrava, dúo cómico que obtuvo gran éxito en los años 60 . Sin embargo, la parodia no discutía los estereotipos de la copla, sino que los reacentuaba [https://www.youtube.com/watch?v=0FJT2JssP-0 acceso 8 enero 2020].
} 
Te sienta que eres un cromo, pero cámbiate de ropa, si es un instante, lo justo mientras me tomo esta copa. Ponte el de cuello cerrao que te está de maravilla y que te llega dos cuartas por bajo de la rodilla.

Es un discurso inapelable, regido por verbos en imperativo: "cámbiate de ropa", "ponte el de cuello cerrao", "coge un poco de agua clara", "a tu prima le devuelves". Es el hombre quien argumenta con autoridad, mientras que la mujer, reducida al papel de receptora sin voz, acata las órdenes del marido:

¿Te cambiaste ya el vestío?

Pues andando p'al teatro,

El mandato patriarcal ("no tienes que engalanarte / pa nadie más que pa mí") queda claro, en la línea de los mensajes de la Sección Femenina: "La vida de toda mujer, a pesar de cuanto ella quiera simular - o disimular - no es más que un eterno deseo de encontrar a quien someterse" (Medina, 1944). El maquillaje y los trucos de belleza son impropios de la mujer casada, pues la perfección radica en su honestidad, por lo que un excesivo cuidado de su imagen podía sugerir que deseaba la mirada de otros hombres.

Coge un poco de agua clara y afuera los melinotes

que te embadurnan la cara;

ni más carmín, ni más cremas,

ni más tintes en el pelo;

no te aguanto más colores

que los que te puso el cielo.

El control del cuerpo y de la sexualidad femenina es uno de los puntales del sistema de moralización impuesto por el Régimen con la militancia activa de la iglesia. Los adornos de la mujer honesta son su gracia natural y la sumisión al esposo. No puede lucir joyas que puedan sugerir que han sido adquiridas de manera fraudulenta y pongan en duda su honra y la del marido.

Y a tu prima le devuelves

la pulsera de brillante, son mucho lujo esas piedras

pa la mujer de un tratante.

Las exigencias expresadas por la autoridad masculina recurren al humor en un discurso que no por eso deja de ser claramente normativo: "el rostro no te lo pintes / ni aunque te salga bigote".

Que con el triguito limpio

toito er mundo te compare,

que por de fuera y por dentro

te parezcas a mi mare.

El modelo de virtud oficial para la esposa, junto a la Virgen María, es la propia madre: mujer sumisa, al cuidado del hogar: "Buscad para novia primero, después para esposa, una chica que se parezca a ese modelo de mujer y madre. [...] Mirad que bajo una apariencia grata puede ocultarse una mujer holgazana y presumida, gastadora e inútil (Junquera, 1961:42; apud Peinado; Anta, 2011:41).

El rechazo a las costumbres foráneas está claramente definido, igual que en Carmen de España. Las estrellas del cine norteamericano, sus recursos de belleza, el tabaco como símbolo de 
mujer emancipada, son modelos negativos, entre los que destaca la mención de Gilda, la película de Charles Vidor (1946). El canto y el baile sensual de Rita Hayworth fue calificado como peligroso por la iglesia española.
Ni más zapatos de Gilda,
Ni más turbantes de raso; para presumir te sobra
con cogerte de mi brazo;

Como en Carmen de España, el modelo de mujer propugnado por la dictadura es nacional, autóctono, antieuropeo y se rige por los dictados del nacionalcatolicismo.
No quiero que me pregunten
"Esa gachona, ¿quién es?,
¿una secretaria de esas
que beben champán francés?"
Ni tú eres mujer moderna
ni quiero que lo aparentes
que yo te prefiero antigua
y oliendo a mujer decente.

En este contexto, aún con el recurso del humor, la violencia queda justificada, como una cuestión intrafamiliar, amparada por la legislación. El marido estaba respaldado por las leyes que condenaban el adulterio, tipificado en el Código Penal de 1944, hasta su derogación en el Código Penal en 1978. "Si la consideración de adulterio aplicado al varón necesitaba ser demostrada mediante una convivencia real con la amante, el solo mantenimiento de relaciones sexuales convertía en adúlteras a las mujeres" (Prieto, 2016:299).
Y como un día te vea
que enciendes un cigarrillo
vas a echar, entrañas mías,
el humo por los tobillos.

\section{B) El saber de las mujeres. La lectura}

La representación de la mujer durante el primer franquismo asume el modelo tradicional que ya denunciara María de Zayas en el siglo XVII (Novelas amorosas y ejemplares): la rueca frente a la pluma, la aguja frente a los libros: "Por tenernos sujetas desde que nacimos, vais enflaqueciendo nuestras fuerzas con temores de la honra, y el entendimiento con el recato de la vergüenza, dándonos por espadas ruecas, y por libros almohadillas" (Zayas de y Sotomayor, 2012:481). Por el contrario, también en el siglo XVII, Juan de Zabaleta (1653) recordará el lugar de las mujeres y su campo de actuación: "Mas, ¿cómo ha de andar casa donde, en lugar de agujas, hay plumas y en lugar de almohadillas, cartapacios?" Lo que reactualiza la Sección Femenina:

¿Qué haría una mujer sin aguja? En todos los tiempos la aguja triunfa: los sudarios de las tumbas de Egipto, los tapices de la Edad Media, los trabajos de la época renacentista, los encajes y bordados maravillosos, etc., son debidos a la habilidad y a la fantasía femeninas (Sección Femenina, Anuario, 1941).

El acceso al saber por parte de las mujeres ha sido tradicionalmente cuestionado y vetado. El conocimiento femenino ha sido reprobado por el patriarcado y las mujeres que han accedido al saber ha recibido apelativos que las ridiculizan (marisabidillas, hembrilatinas, cultiparlantes, literatas): "Las mujeres nunca descubren nada; les falta, desde luego, el talento creador, reservado por Dios para inteligencias varoniles; nosotras no podemos hacer más que interpretar, mejor o peor, lo que los hombres nos dan hecho" (Primo de Rivera, 1943:7). Así lo expresa un director de Enseñanza Media, en una entrevista publicada en la revista Signo (1942): "Debe alejarse a la mujer 
de la Universidad, quiero decir que el sitio de la mujer, a mi juicio, es el hogar" (Pastor i Homs, 1984:31).

En este contexto, la ridiculización de la mujer lectora cobra sentido y así lo muestran dos coplas fundamentales: La niña de la estación (1941) y Lolita la musaraña, (1948). Junto a estas, cabe destacar la letra de Los niños de la Gabriela (1948), que aborda la lectura en la mujer con un valor claramente instrumental en el entorno familiar y, por ello, a pesar del guiño humorístico, la protagonista es mirada con cariño y compasión.

La comicidad en las dos primeras se sustenta tanto en el uso hiperbólico y metafórico del léxico, como en las situaciones y en las referencias a obras y a personajes literarios. La niña de la estación es el retrato de una mujer que, en su deseo de encontrar novio, pierde la razón y se ve envuelta en trances disparatados. Con la esperanza de encontrar al príncipe azul, va a la estación a ver pasar los trenes y a esperar que algún hombre se enamore de ella.

Aunque esta copla podría muy bien encuadrarse dentro del tercer grupo que vamos a considerar, el de las solteronas, la analizamos aquí porque la representación de la protagonista responde fundamentalmente al modelo de mujer lectora, ridiculizada por el patriarcado.

Las referencias a los poetas románticos son explícitas: "Los suspiros son aire y van al aire, / las lágrimas son agua y van al mar" (Bécquer); "Volverán las oscuras golondrinas / en tu balcón sus nidos a colgar" (Bécquer); "Mi carta que es feliz, pues va a buscaros, / cuenta os dará de la memoria mía" (Campoamor).

Parte de la comicidad de la letra se sustenta en la revisión de los versos consagrados por el canon, que serán alterados y ridiculizados, bien por el uso del lenguaje coloquial o por la introducción de un personaje insólito en el andamiaje de las estrofas de poetas reconocidos, como es el caso del empleado de Correos que altera y rebaja el lirismo de la rima LIII de Bécquer.

Volverán las oscuras golondrinas en mi balcón sus nidos a colgar, pero aquel ambulante de Correos, aquél no volverá.

También la pregunta retórica de la rima XXXVIII de Bécquer ("Dime, mujer, cuando el amor se olvida /¿sabes tú adónde va?) queda rebajada por la parodia del verbo coloquial "pirarse", que da el contrapunto a la situación.

Los suspiros son aire y van al aire,

las lágrimas son agua y van al mar.

Dime, mujer, cuando un amor se pira,

¿sabes tú dónde va?

Los versos de Campoamor forman el leit motiv de la copla, pues su referente es El tren expreso: "Mi carta, que es feliz, pues va a buscaros, / cuenta os dará de la memoria mía. / Aquel fantasma soy que, por gustaros, / juró estar viva a vuestro lado un día" (Canto III).

Mi carta que es feliz, pues va a buscaros,

cuenta os dará de la memoria mía.

Aquella mujer soy, que de esperaros,

se quedó en la estación, helada y fría.

La parodia de la obra de Campoamor perfila en esta copla a una protagonista cursi, lejos del modelo de mujer aceptado, encerrada en el hogar y atenta al cuidado de la familia. Por el contrario, Adelina, es la representación de lo reprobado socialmente. Su apelativo, niña de la estación, la sitúa como una mujer excéntrica, lejos de la costura y del silencio de la cancela, una mujer que ha perdido la cabeza a causa de sus lecturas: "con un libro entre las manos / de Bécquer o Campoamor".

Era delgada y morena,

era de cintura fina,

era más cursi que un guante 
la señorita Adelina.

Y como ver pasar trenes

era toda su pasión,

en el pueblo la llamaban

La Niña de la Estación.

La historia de amor de Adelina es siempre imposible. Está en un lugar que no le corresponde, pues es la mujer la que debería esperar al varón, en su casa, tras la ventana o la cancela. La fugacidad del tren reacentúa lo absurdo de la situación y de sus actos, en la búsqueda de marido. Tras su matrimonio con el jefe de estación, el fallecimiento del esposo la deja nuevamente ridiculizada en su pretensión de encontrar nueva pareja.

El humor disparatado ridiculiza la situación, incluso en los momentos más dramáticos, con el uso figurado del léxico (fiambre), que rebaja la altura dramática del momento.

Pasaron meses y meses

y aquel galán no volvió

y Adelina se ha casado

con el jefe de estación.

Pero con tan mala suerte

que, a los dos días del hecho,

murió su pobre marido

de dos anginas de pecho.

Y la pobre medio loca

creyéndose en la estación

cuando ya se lo llevaban

así al fiambre cantó:

Lolita la musaraña retrata a una mujer que ha perdido el sentido por culpa de su fantasía desbordada, provocada por su afición a la lectura, tal y como le recrimina el marido: "Lolita, tú estás pensando / na más que en los folletines”.

Como en otras coplas, el título da cumplida cuenta del drama mayor o menor que se va a escenificar. En este caso, la aposición "la musaraña" define la intencionalidad de la obra al incorporar en el nombre de la protagonista el principal rasgo de su carácter: la continua distracción. Esto podía ser fácilmente interpretado por el público, pues la expresión "mirar a las musarañas" es muy conocida popularmente.

La imagen de la mujer lectora, devoradora de folletines, se ha asociado a la posibilidad de transgredir las normas y de ser, por tanto, el blanco de habladurías o bien de protagonizar conductas prohibidas, en la estela de Madame Bovary. Es lo que a finales del siglo XIX se denominó Bovarismo: "Se establecieron dentro del imaginario cultural decimonónico cómo las representaciones emblemáticas de la lectora cuya incapacidad de discernir la diferencia entre texto y fantasía la arrollaba, inevitablemente, hacia la trasgresión sexual" (Blanco, 1996:16).

A igual que en La niña de la estación, los intertextos son reconocibles, pues se refieren a obras muy conocidas. Si bien Adelina era lectora preferentemente de poesía, en el caso de Lolita las lecturas referenciadas son narrativas:

Pensando en la gran fortuna

del conde de Montecristo,

metió un tomate en la cuna

y a la criatura la echó en el pisto.

-iQuién hable mal de Rebeca

no tiene perdón de Dios!

-iYo soy los Tres Mosqueteros

y mi señora, nuestro asistente! 
Si tú fuiste antes de ahora

la suegra de Gulliver,

yo soy la locomotora

del mixto de Santander.

La copla se estructura en tres partes que finalizan con un estribillo. Como una tragicomedia en tres actos, la obra presenta una primera parte introductoria en la que se presenta a la protagonista, con detalles aún más dramáticos y grotescos que en La niña de la estación.

Los ojos desencajados, con una mirada extraña, camina por todos lados

Lolita La Musaraña.

La obra se construye como un aviso para los maridos. Si bien en la primera parte Lolita da sobradas muestras de su locura, por el excesivo interés hacia la lectura de folletines, en la segunda ya no es el novio, sino el marido, el que ha de enfrentarse a las múltiples catástrofes que la actitud de su mujer genera por no estar pendiente de su hogar. La tercera es la conclusión que, a modo de moraleja, da cuenta del contagio de la locura que ha sufrido el esposo, por no ser capaz de atajar a tiempo los desmanes de Lolita. Una vez ella recobra la cordura es él quien ha perdido cualquier referente de sensatez.

La comicidad se sustenta en diferentes recursos retóricos: "¿Por qué va tan distraída, / que por la calle tropieza / con los camiones y los tranvías?" (hipérbole); "metió un tomate en la cuna / y a la criatura la echó en el pisto" (hipérbole); "yo tengo el coco / con telarañas!" (metáforas) "cara de lila" (metáfora); giros coloquiales: "ilgual que una regadera / está Lolita La Musaraña!"; (estribillo); "iMata la araña, pipiritaña, / tu cabecera con telarañas! (jitanjafora y nonsense).

La comicidad de situaciones reproduce un escenario familiar en el que las chifladuras de la mujer y el consecuente desequilibrio del marido, a causa de los dislates de la esposa, distorsionan la realidad y avisan de los peligros de la lectura. El descuido de sus obligaciones como madre se narra en versos hilarantes.

Lo saca el esposo

de la cacerola

y exclama furioso

mirando a la Lola:

Lolita, tú estás pensando

na más que en los folletines,

y al niño lo estás guisando

como a los calabacines.

Pero las extravagancias del marido no son menores, aunque sí disculpables, puesto que las sufre por influencia de la esposa.

Camina por el alero

diciéndole así a la gente:

-iYo soy los Tres Mosqueteros

y mi señora, nuestro asistente!

Del susto Lolita

llorando se queja,

y el otro le grita

"colgao" de una teja:

Caso muy diferente es el de la protagonista de Los niños de la Gabriela. Se trata de una mujer analfabeta que está mirando un periódico invertido. Sin embargo, no aparece ridiculizada, sino que el tono es serio y compasivo. Transmite ternura esa madre de tres toreros que trata de leer un periódico porque busca noticias sobre la faena de sus hijos, en diferentes plazas de toros. La mujer se sitúa en el espacio privado ("La Gabriela, vela, vela, / la Gabriela, vela, va, / sentadita en 
la cancela"). Las metáforas, lejos del humor, remiten a la descripción de la protagonista, a la que se presenta con el respeto que produce su edad ("en la plata de su pelo"), su condición de madre ("son tres clavos de amargura / los hijos de la Gabriela") y la angustia ("pero tengo un cuchillito / que me ronda la cintura"). Nuevamente los versos conducen a otro intertexto de Ramón de Campoamor ("iQuién supiera escribir!").

Corta un suspiro la tarde:

iAy, quién supiera leer!-

$Y$ entre temblona y risueña, con el papel del revés, va mirando la reseña.

\section{C) La solterona}

La mujer soltera carece de posibilidades económicas para ser independiente y es socialmente mirada con desprecio, compasión e incluso ridiculizada en tiras cómicas: Floripondia Piripí, se pirra por dar el sí; Margarita Gautiérrez, la dama de los cabellos, en referencia intertextual a La Dama de las Camelias.

Retratos y revisiones del arquetipo de la mujer soltera se encuentran en obras de teatro (Sublime decisión, de Miguel Mihura), en un ensayo tan significativo como Usos amorosos de la posguerra española, de Carmen Martín Gaite y en las novelas de Dolores Medio y Carmen Laforet: "La señorita Quintana era el clásico tipo de solterona de clase media del primer cuarto de siglo: parásito de la hermana casada, alcahueta de sus sobrinos, sentimental, inocente, un poco cursi" (Medio, 1953:74). Frente a estas, estarían las mujeres que triunfan en el amor, a pesar de las dificultades, muchas de ellas protagonistas de las novelas de Corín Tellado: "las solteronas que habían sido incapaces de participar del mercado matrimonial eran un arquetipo femenino extraño al cuerpo social: seres desnaturalizados, amputados, dependientes, dignas de lástima" (Peinado; Anta, 2013:42).

La soltera protagoniza un nutrido grupo de coplas. Las imágenes responden a varios estereotipos que van desde la mujer que ha recibido propuesta de matrimonio y realiza los preparativos para la boda, hasta la joven seducida y abandonada por un hombre rico y poderoso. En relación con esta última estarían la madre soltera, la prostituta y "la otra", mantenida y amante de un casado. En este caso la doble vida es aceptada socialmente y la esposa se convierte en consentidora del desprecio y la humillación con tal de no perder su estatus ( Tú eres mi marío).

Por otro lado, existe un número menor, pero muy significativo, de letras en las que se retrata a la solterona como la mujer que no encuentra quien la quiera y por tanto verá frustrado el proyecto vital de esposa y madre para el que ha sido educada. Las razones que dificultan el objetivo son de diversa índole (belleza, rango social, edad).

Cuando la joven es poco agraciada físicamente está condenada a la invisibilidad entre los hombres (Picadita de viruela). Sin embargo, responder al canon social de mujer honesta, puede salvar estas dificultades y facilitar el camino hacia el altar.

En otras coplas, la mujer tiene dificultades para encontrar pareja en el entorno social que le corresponde por clase. Es estos casos, las letras ofrecen argumentos en los que el concepto de amor romántico, entendido como el único y verdadero, salva todos los obstáculos y la protagonista encuentra una vida digna del brazo de alguien más joven y pobre, pero rendido a su persona (Doña Soledad). En esta línea dramática, pero sin final feliz, encontramos la crónica de la amargura de una mujer anciana que no ha podido encontrar el amor en su larga vida (Señorita).

Pero, en nuestro acercamiento, nos interesan aquellas coplas que abordan el tema desde una perspectiva humorística. Por ello analizamos tres obras que, aunque coinciden en el tono lúdico, sin embargo, aportan matices diferentes. Por una parte, encontramos dos coplas en las que la mujer es abandonada (Soltera y Compuesta y sin novio) y, por otra, una en la que se cumple el objetivo final del matrimonio ( $A$ la lima y al limón). 
A la lima y al limón (1941) es una letra cercana en su mensaje a Picadita de viruela. En ambos casos se trata de mujeres que no responden al canon de belleza física establecido, pero que aun así son redimidas por el amor de un hombre.

La vecinita de enfrente -no, no-

no tiene los ojos grandes,

ni tiene el talle de espiga -no, no-,

ni son sus labios de sangre.

La justicia poética se instala en la copla, pues no solo encuentra un novio, sino que es de elevada posición social ("se ha casado / con un señor de cincuenta -sí, sí- / que dicen que es magistrado"). Como ocurría en Mi trigo limpio, la mujer luce orgullosa del brazo del marido.

Lo luce por los paseos,

lo luce por los teatros

y va siempre por la calle

cogidita de su brazo.

Tanto en Picadita de viruela como en $A$ la lima y al limón una cantinela atormenta los oídos de sus protagonistas. Es el runrún de la calle que llega a modo de estribillo: "Picadita, picadita, / picadita de viruela"; "A la lima y al limón, / te vas a quedar soltera".

Mucho más agresiva en su mensaje es Soltera, frente a Señorita, que describe en tono dramático y compasivo el amor frustrado y La niña de la estación que, en clave paródica, introduce diversos intertextos literarios.

La voz narrativa de Soltera es masculina. Es un primo de la protagonista quien narra la crónica de sus fracasos amorosos. Centra su mirada en dos objetivos: en la descripción de la mujer y en el relato de la llegada y huida de los pretendientes.

El personaje de Matilde es ridiculizado con diferentes recursos. Las metáforas, analogías y símbolos aluden a la soledad impuesta. La identificación de la mujer con el entorno es total en los versos siguientes, con la analogía entre la fuente y los infortunios de la protagonista.

Patio de mosaicos,

zaguán y cancela

$y$ en medio del patio

una fuente muerta.

La mantilla negra, el abanico negro y el rosario simbolizan la asfixia, el luto impuesto a la mujer que no ha conseguido el triunfo social: un marido. Los estrechos márgenes patriarcales le permiten acudir a la iglesia y la copla la retrata con una cruel analogía: "iCirio de Cuaresma!", lo que popularmente se denominaba "quedarse para vestir santos". Y la súplica directa ("iSeñor, no quiero / quedarme soltera!") se crece en la metáfora "rosario que llora".

Tras esta descripción, la copla discurre por una extensa enumeración de los pretendientes que van llamando sucesivamente a su puerta y a los que el infortunio aleja inexorablemente. Son cinco los hombres que llegan hasta su cancela. Se narran breves pinceladas de sus acciones, aunque el relato va haciéndose más breve según avanza la copla hasta quedarse en una mera enumeración de los candidatos.

1)

Un hombre, el primero,

llamó a su cancela

y al mes de noviazgo

la calle desierta;

2)

Aquel primo

que bailó con ella

una vez, y luego

murió allá en la guerra. 
3)

Luego... el extranjero

que vino a las fiestas

con lentes de oro

y rubias guedejas

y un idioma dulce

como de ciruela,

que habló de casarse...

$y$ se fue a su tierra.

4)

Después vino un suave

profesor de orquesta;

5)

Más tarde, un delgado

maestro de escuela.

La ridiculización de la mujer se reacentúa en los versos finales y la maldad popular surca las calles en una cantinela cruel:

Cada año que pasa

mi prima se queda

compuesta y sin novio,

iCirio de Cuaresma!

Sevilla murmura:

"Soltera..., soltera".

Compuesta y sin novio (1944) aborda una de las situaciones de mayor desgracia para las mujeres: ser abandonada poco antes de casarse. Sin embargo, la protagonista de esta copla no muestra pesar, sino que, con una voz bivocal, afirma que se considera afortunada. Sus argumentos se sitúan en la descripción desproporcionada de los hijos del antiguo novio y de la vida que lleva con su esposa.

La dilogía muestra una voz despechada que encuentra múltiples razones para justificar su suerte, en una situación considerada socialmente desgraciada: ser abandonada por el novio. Aun así, ella es capaz de plantear cómicamente los acontecimientos de manera que da la vuelta a lo sucedido.

Yo tuve un novio barbero

y una vecina me lo quitó;

tuvieron tres churumbeles

con la cabeza como un farol.

El humor de situaciones y la hipérbole caracterizan esta copla en la descripción de la cabeza de los hijos del barbero y la inestabilidad del edificio como consecuencia de su desproporción.

tuvieron tres churumbeles

con la cabeza como un farol.

$[\ldots]$

por eso duermen de noche

las tres cabezas en el balcón.

La casa se bambolea

con aquel peso fenomenal

[...]

Con el barbero,

no me he casado,

del terremoto de San Francisco

yo me he librado 
La copla se convierte también en un alegato contra el matrimonio y la familia política (suegros, cuñados), dentro de la cultura popular con razones cercanas al refranero (la que no tiene suegra y cuñada, es bien casada).

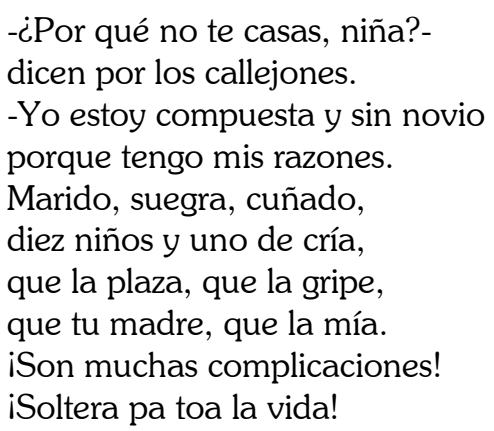

\section{Conclusiones}

Con este acercamiento hemos pretendido aportar una línea de indagación sobre la influencia de la cultura popular en la educación sentimental durante el franquismo. En este caso, con especial atención a coplas humorísticas y paródicas. La copla, como texto ampliamente difundido a través de la radio, transmite múltiples referencias normativas que contribuyen a la educación sentimental de varias generaciones, a partir de los años cuarenta del pasado siglo. Las imágenes de mujeres y de hombres reproducen estereotipos de género donde pueden leerse modelos prescriptivos.

La mayoría de coplas popularizadas por Concha Piquer, Imperio Argentina, Estrellita Castro, Juanita Reina y Lola Flores entre otras, responden a narrativas dramáticas, sin embargo encontramos un corpus más reducido que utiliza el humor como recurso para revisar y criticar los mandatos de género sobre las mujeres.

Aunque las limitaciones de nuestro análisis vienen determinadas por el hecho de ser un corpus de ocho coplas, sin embargo, son muy ricas y significativas, por lo que queda abierta una línea de trabajo para continuar profundizando en el papel del humor en la representación de modelos y estereotipos en el franquismo, dentro del marco de los estudios de género y de la cultura popular en la posguerra española. Del mismo modo cabe otra línea de análisis comparativo entre los modelos discursivos de las coplas dramáticas frente a las que se valen de la subversión paródica.

La selección del corpus obedece a tres parámetros interrelacionados en la construcción de modelos de mujer tras la guerra civil. Las coplas analizadas trazan el perfil de la mujer española, dedicada al hogar, sin independencia económica ni acceso a los estudios. Este papel lo cumplía absolutamente la soltera, pues era frecuente que se ocupara de los padres e incluso de sobrinos y sobrinas.

Los personajes de estas coplas dialogan con otras representaciones de la subjetividad femenina, opuestas también al ideal de la "perfecta casada", de enorme éxito como Ojos verdes popularizada por Concha Piquer. Las historias narradas, ya sea en clave dramática o humorística, muestran asuntos fácilmente reconocible por los receptores. La intertextualidad paródica, que presentan algunos textos como Lolita la musaraña o La niña de la estación, reacentúa la crítica en narraciones sesgadas que son interpretadas por un público conocedor de los modelos canónicos de conducta. A través de la comicidad verbal y de situaciones, los personajes masculinos y femeninos ofrecen un mosaico de modelos y la revisión de los mismos.

Los relatos paródicos o trágicos se construyen con gran riqueza de figuras retóricas y referencias cercanas a la cultura popular y al refranero. En el caso de las coplas humorísticas, el sentido figurado de las palabras, la caricaturización de personajes y la parodia de citas textuales, provocan sonrisas cómplices y trazan perfiles de mujeres que son rechazadas por transgredir las normas vigentes.

Las coplas de Rafael de León ofrecen un rico campo de estudio para profundizar en la configuración de identidades a través de la representación de estereotipos de género. El uso del humor no resta eficacia a la transmisión de las normas, sino que reacentúa el modelo oficial y fija 
ejemplos de castigo para las transgresiones de las mujeres, a la vez que sirve de ejemplo para los varones.

Vistas las coplas como documentos históricos, se constituyen en útiles instrumentos para trazar las huellas de la sentimentalidad de una época. Los recursos retóricos con los que se expresa el humor (hipérboles, metáforas, coloquialismos, dilogía, parodia) fijan con gran eficacia el modelo de mujer española sumisa, cristiana y decente, frente a las inaceptables influencias foráneas.

\section{Referencias bibliográficas}

ACOSTA DÍAZ, Josefa et al. Poemas y canciones de Rafael de León. Sevilla, Alfar, 1997.

ARCHER, Robert Misoginia y defensa de las mujeres. Antología de textos medievales. Madrid, Cátedra Feminismos, 2001.

BLANCO, Alda. Escritora, feminidad y escritura en la España de medio siglo. En: ZAVALA, Iris (coord.). Breve historia feminista de la literatura española (en lengua castellana) $V$. La literatura escrita por mujer (del s. XIX a la actualidad). Barcelona, Anthropos, 1996, pp.9-38.

BORDIERA, E.; MARTÍNEZ, F.; MOMPART, J. El humor frente al poder: prensa humorística, cultura política y poderes fácticos. Madrid, Biblioteca Nueva, 2015.

BOSH, Esperanza; FERRER, Victoria; GILI, Margarita. Historia de la misoginia. Palma de Mallorca, Anthropos Editorial, 1999.

GÓMEZ CAPUZ, Juan. Mecanismos del lenguaje humorístico (con especial atención al nivel pragmático). Oralia, 5, 2002, pp.75-101.

HIDALGO DOWNING, Raquel; IGLESIAS RECUERO, Silvia. Humor e ironía: una relación compleja. En: RUIZ GURILlO, L; PADILLA, X (ed.). Dime cómo ironizas y te diré quién eres. Franfurt, Peter Lang, 2009, pp.423-455.

HURTADO BALBUENA, Sonia. La copla: la poesía popular de Rafael de León. Fundación Unicaja, Málaga, 2006.

IMBERT, Gerard. Elena Francis, un consultorio para la Transición. Barcelona, Península, 1982.

IZQUIERDO, José María. Carmen Martín Gaite + Tzvetan Todorov = El cuarto de atrás (1978). En: ENKVIST, Inger; IZQUIERDO, José María (ed.). Actas del Simposio Internacional sobre la obra de Tzvetan Todorov, 2004, pp.17-27.

MARTÍN GAITE, Carmen. Usos amorosos de la posguerra española. Madrid, Anagrama, 1987.

MARTÍN GAITE, Carmen. Cuarto a espadas sobre las coplas de posguerra. Revista Triunfo, n. 529, año XXVII, 18/11/1972, pp.36-39.

MEDINA, Revista de la Sección Femenina, 13 de agosto de 1944.

MEDIO, Dolores. Nosotros, los Rivero. Barcelona, Destino, 1953.

MOIX, Terenci. Suspiros de España: La copla y el cine de nuestro recuerdo. Barcelona, Plaza \& Janés, 1993.

MORAGA GARCíA, María A. Notas sobre la situación jurídica de la mujer en el Franquismo. Feminismos, 12, 2008, pp.229-252.

NÚÑEZ RAMOS, Rafael. Semiótica del mensaje humorístico. En: GARRIDO GALLARDO, M. A. (ed.). Teoría semiótica. Lenguaje y textos hispánicos. Madrid, CSIC, 1984, pp.269-275.

PASTOR I HOMS, María I. La Educación femenina en la postguerra (1939-1945). El caso de Mallorca. Madrid, Ministerio de Cultura, 1984.

PEINADO RODRÍGUEZ, Matilde; ANTA FÉLEZ, José Luis. Educar para el matrimonio en femenino: modelos y prácticas en la literatura de posguerra. Athenea Digital, 13(2), 2013, pp.35-46.

PRIETO BORREGO, Lucía. La copla: un instrumento para el proyecto de moralización de la sociedad española durante el primer franquismo. Arenal, v. 23 n. 2, 2016, pp.287-320.

PRIMO DE RIVERA, Pilar. Conferencia en el Primer Consejo del S.E.M., en $A B C 6$ febrero 1943, p.7. 
RAMOS ROVI, María J. La imagen de la mujer en la historieta del Franquismo. Historia actual online, 43 (2), 1917, pp.159-168.

REINA, Manuel F. Un siglo de copla. Barcelona, Ediciones B, 2009.

ROMÁN, Manuel. Los grandes de la copla. Historia de la canción española. Madrid, Alianza, 2010.

ROSAL NADALES, María. Poética de la sumisión. Malos tratos y respuestas femeninas en las coplas. Almería, Instituto de Estudios Almerienses, 2011.

SECCIÓN FEMENINA. La mujer y la aguja, Anuario, 1941. En: OTERO, Luís, La Sección Femenina. Madrid, EDAF, 2004, p.177.

SECCIÓN FEMENINA. Economía doméstica para Bachillerato, Comercio y Magisterio, 1968.

TÉLLEZ, Juan José. Copla, flamenco y canción de autor. Música oral del sur, n. 9, Junta de Andalucía, Centro de Documentación Musical, 2011, pp.102-153.

VÁZQUEZ MONTALBÁN, Manuel. Cancionero general del franquismo 1939-1975. Barcelona, Editorial Crítica, 2000.

ZABALETA, Juan de. Error VIII. En: Errores celebrados, 1653 [https://www.ensayistas.org/antologia/XVII/zabaleta/zabaleta3.htm - acceso el 8 de enero 2020].

ZAYAS DE Y SOTOMAYOR, María. La fuerza del amor. Novelas amorosas y ejemplares. En: SUÁREZ LEMIR, Enrique (ed.). Lemir, 16, 2012, pp.353-572. 